\title{
$\alpha$-Tocopherol in breast milk of women with preterm delivery after a single postpartum oral dose of vitamin $\mathrm{E}$
}

\author{
Jeane Franco Pires Medeiros ${ }^{1 *}$, Karla Danielly da Silva Ribeiro ${ }^{1}$, Mayara Santa Rosa Lima ${ }^{1}$, \\ Renata Alexandra Moreira das Neves ${ }^{2}$, Amanda Cibely Pinheiro Lima ${ }^{1}$, Raquel Costa Silva Dantas ${ }^{1}$, \\ Alyne Batista da Silva ${ }^{1}$ and Roberto Dimenstein ${ }^{1}$ \\ ${ }^{1}$ Department of Biochemistry, Federal University of Rio Grande do Norte, Ave. Senador Salgado Filho 3000, Lagoa Nova, Natal, \\ 59072-970, Brazil \\ ${ }^{2}$ Department of Nutrition, Federal University of Rio Grande do Norte, Ave. Senador Salgado Filho 3000, Lagoa Nova, Natal, \\ 59072-970, Brazil
}

(Submitted 30 October 2015 - Final revision received 21 January 2016 - Accepted 25 January 2016 - First published online 2 March 2016)

\begin{abstract}
We evaluated the effect of maternal vitamin E supplementation on the $\alpha$-tocopherol concentrations of colostrum, transitional milk and mature milk of women who had given birth prematurely. This longitudinal randomised-controlled trial divided eighty-nine women into two groups: a control group and a supplemented group. Blood and breast milk were collected from all the participants after delivery. Next, each woman in the supplemented group received $400 \mathrm{IU}$ of RRR- $\alpha$-tocopheryl acetate. Further breast milk samples were collected $24 \mathrm{~h}$ after the first collection, as well as 7 and $30 \mathrm{~d}$ after delivery. $\alpha$-Tocopherol concentrations were determined by HPLC. The baseline $\alpha$-tocopherol concentrations in the maternal serum of the two groups were similar: $1159 \cdot 8$ (sD 292.4) $\mu \mathrm{g} / \mathrm{dl}(27.0$ (sD 6.8) $\mu \mathrm{mol} / \mathrm{l}$ ) for the control group and 1128.3 (sD 407.2) $\mu \mathrm{g} / \mathrm{dl}$ (26.2 (sD 9.5) $\mu \mathrm{mol} / \mathrm{l}$ ) for the supplemented group. None of the women was vitamin E deficient. Breast milk $\alpha$-tocopherol concentrations increased by $60 \% 24 \mathrm{~h}$ after supplementation in the intervention group and did not increase at all in the control group. $\alpha$-Tocopherol concentration of the transitional milk in the supplemented group was $35 \%$ higher compared with the control group. $\alpha$-Tocopherol concentrations of the mature milk in both groups were similar. Maternal supplementation with 400 IU of RRR- $\alpha$-tocopherol increased the vitamin E concentrations of the colostrum and transitional milk, but not of the mature milk. This study presents relevant information for the design of strategies to prevent and combat vitamin $\mathrm{E}$ deficiency in the risk group of preterm infants.
\end{abstract}

Key words: Dietary supplementation: Clinical trials: Intervention studies: Liquid chromatography

Preterm infants are more susceptible to vitamin E ( $\alpha$-tocopherol) deficiency because they are born with low body reserves and low serum levels of this micronutrient ${ }^{(1)}$. This deficiency may stem from limited placental transfer, low body fat, tocopherol accumulation that occurs mainly during the third trimester of pregnancy associated with an increase in body fat and higher nutritional requirements ${ }^{(2,3)}$. As a consequence, newborns are more susceptible to infections, thrombocytosis, haemolytic anaemia, retrolental fibroplasia, intraventricular haemorrhage, bronchopulmonary dysplasia and spinocerebellar ataxia ${ }^{(4)}$.

Appropriate nutritional support should be provided for preterm infants to prevent the damage caused by vitamin E deficiency, and breast milk is considered the ideal food for meeting all of the newborn's nutritional requirements ${ }^{(5)}$. Breast milk has been associated with many benefits such as better immunity, digestion, nutrient absorption, gastrointestinal function and neurodevelopment ${ }^{(6,7)}$.
However, preterm infants require higher serum levels of the antioxidant $\alpha$-tocopherol than those reached with routine oral doses of vitamin $\mathrm{E}^{(8)}$ to eliminate free radicals and reduce the risk of lipid peroxidation and oxidative injury ${ }^{(9)}$.

Experts have suggested giving vitamin E supplements to preterm infants to prevent vitamin $\mathrm{E}$ deficiency ${ }^{(1,10)}$; however, many challenges are associated with vitamin and trace-element supplementation of newborns because their basic requirements, appropriate administration route and proper dosage are not well defined and vary considerably ${ }^{(11-13)}$. Moreover, breast milk vitamin E concentrations may fall during lactation ${ }^{(14)}$. Therefore, fortification of breast milk through maternal vitamin E supplementation may be a good way to protect newborns from the effects of vitamin E deficiency. The objective of the present study was to assess the effect of vitamin E supplementation on the $\alpha$-tocopherol concentrations of colostrum, transitional milk and mature milk of women who had given birth prematurely.

Abbreviations: CG, control group; SG, supplemented group.

* Corresponding author: J. F. Pires Medeiros, fax +55 843342 2812, email jeanefpires@hotmail.com 


\section{Methods}

\section{Participants}

The participants were women aged between 18 and 45 years seen at the Maternity Hospital Escola Januário Cicco and Pediatric Hospital Professor Heriberto Ferreira Bezerra (HOSPED), both located in the city of Natal, RN, Brazil. All the women had delivered preterm (gestational age $<37$ weeks). Gestational age was calculated based on the date of the last menstrual period or ultrasounds. The women joined the study between November 2013 and July 2014. Exclusion criteria were as follows: use of multivitamins during pregnancy, presence of diabetes, high blood pressure, neoplasm, gastrointestinal disease, liver disease, heart disease, infectious disease and syphilis and positive HIV status.

This study was conducted according to the guidelines laid down in the Declaration of Helsinki, and all the procedures were approved by the Research Ethics Committee of the Federal University of Rio Grande do Norte in compliance with Resolution 466/12 and under protocol number 461464. The clinical trial was approved by the Brazilian Registry of Clinical Trials under the number RBR-9gycqb. All the participants were informed of the study objectives and they signed an informed consent form before joining the study.

The minimum sample size was calculated by the software G*Power version $3.1 .7^{(15)}$ using the following parameters: an $\alpha$ of $5 \%$, power of $80 \%$ and expected effect of $0 \cdot 30$. Therefore, each group should have had at least twenty individuals.

\section{Study intervention}

This randomised-controlled trial had two treatment arms: a treatment-free control group (CG) and a supplemented group (SG) that received a single oral dose of 400 IU natural vitamin $\mathrm{E}$ in the form of RRR- $\alpha$-tocopheryl acetate. The dosage of $400 \mathrm{IU}$ RRR- $\alpha$-tocopherol was chosen because it has been considered safe by the Institute of Medicine ${ }^{(16)}$, which conducted long-term studies to investigate the toxic effect of this dosage and found no deleterious effects.

The supplement was given after the first blood and colostrum collection, within $48 \mathrm{~h}$ of delivery. Randomisation followed the daily delivery order: the first woman to deliver was placed in the CG, the second in the SG and so on. Initially both groups had the same number of participants, but some were lost to follow-up after hospital discharge or newborn death.

\section{Data collection}

Obstetric, newborn and maternal socio-economic data were collected from all the participants by the administration of a structured questionnaire by the researcher. The gestational age of the newborn was calculated based on the date of the last menstrual period or ultrasound. Pre-gestational nutritional status was given by the mother's pre-gestational BMI, where maternal weight is divided by the square of maternal height $\left(\mathrm{kg} / \mathrm{m}^{2}\right)^{(17)}$.

Blood $(5 \mathrm{ml})$ and colostrum $(2 \mathrm{ml})$ were collected from all the participants within $48 \mathrm{~h}$ of delivery. The SG received the vitamin E capsule immediately after this baseline blood and breast milk collection ( 0 -h milk). Colostrum ( $2 \mathrm{ml}$ ) was again collected from both the groups $24 \mathrm{~h}$ after the first collection (24-h milk), transitional milk ( $2 \mathrm{ml})$ was collected $7 \mathrm{~d}$ (7-d milk) after delivery and mature milk $(2 \mathrm{ml})$ was collected $30 \mathrm{~d}$ after delivery (30-d milk). All the samples were collected after an overnight fast.

Blood was obtained by venepuncture and centrifuged for $10 \mathrm{~min}$ at $1073 \boldsymbol{g}$ to separate $1 \mathrm{ml}$ of serum. Breast milk was collected manually from the breast, which had not been suckled for at least $2 \mathrm{~h}$. The first droplets were discarded to avoid fat content variations. A 500- $\mu$ l aliquot of colostrum and $1 \mathrm{ml}$ of transitional and mature milk were separated for vitamin $\mathrm{E}$ extraction. All samples were stored at $-20^{\circ} \mathrm{C}$ until analysis.

To determine whether colostrum, transitional milk and mature milk met the vitamin E requirements of infants aged 0-6 months $(4 \mathrm{mg} / \mathrm{d})^{(16)}$, we considered that preterm infants ingest $254 \mathrm{ml} / \mathrm{d}$ of breast milk during the 1st week of life, as suggested by Bauer \& Gerss ${ }^{(18)}$, and $552 \mathrm{ml} / \mathrm{d}$ of mature milk at 1 month of age ${ }^{(19)}$.

\section{Chemical analyses}

$\alpha$-Tocopherol was extracted from breast milk as recommended by Ortega et $a l .{ }^{(20)}$, with adaptations. $\alpha$-Tocopherol concentrations were determined by HPLC using a Shimadzu LC-20AT chromatograph (Shimadzu Corporation), with an injector loop of $20 \mu \mathrm{l}$, connected to a CBM 20A communicator (Shimadzu Corporation) and SPD-20A UV-VIS detector (Shimadzu Corporation). Chromatographic separation was achieved using a LiChroCART 250-4 reverse-phase column (Merck). $\alpha$-Tocopherol was identified and quantified by comparing the area of the chromatographic peak with the respective $\alpha$-tocopherol standard $\left(\right.$ Sigma $\left.{ }^{\circledR}\right)$. The concentration of the standard was confirmed by the extinction coefficient specific for $\alpha$-tocopherol $(1 \%, 1 \mathrm{~cm}=75.8$ for $292 \mathrm{~nm})$ in absolute ethanol $\left(\text { Merck }^{\circledR}\right)^{(21)}$. Mothers with serum $\alpha$-tocopherol levels lower than $12 \mu \mathrm{mol} / 1$ $(516 \mu \mathrm{g} / \mathrm{dl})$ were considered vitamin E deficient ${ }^{(16)}$.

\section{Statistical analysis}

$\alpha$-Tocopherol concentrations in the serum and breast milk of the CG and SG were compared using IBM SPSS Statistics version 21.0 for Windows (SPSS Inc.). The significance level was set at $5 \%(P<0.05)$. The Kolmogorov-Smirnov test was used to verify sample symmetry. The Mann-Whitney and $\chi^{2}$ tests were used to compare the maternal and newborn characteristics of the two groups.

The Mann-Whitney test compared the variables that were not normally distributed (vitamin $\mathrm{E}$ in serum, 0-h milk and 24-h milk). The $t$ test for independent measurements compared variables with near-normal distribution (7-d and 30-d milks) and verified variance homogeneity.

\section{Results}

A total of eighty-nine women (fifty-one in the CG and thirtyeight in the SG) met the inclusion criteria. New sample losses occurred throughout the study starting on day 7. Most losses 
were due to infant death, no production of breast milk and dropouts. Therefore, the number of participants per collection were as follows: $7 \mathrm{~d}(n$ 42) and $30 \mathrm{~d}(n$ 33) for the CG and $7 \mathrm{~d}$ ( $n$ 33) and $30 \mathrm{~d}(n$ 22) for the SG.

Table 1 shows the general characteristics of the mothers and newborns. The CG and SG had similar characteristics.

The mean $\alpha$-tocopherol concentration in the serum of the control mothers (1159.8 (sD 292.4) $\mu \mathrm{g} / \mathrm{dl} ; 27 \cdot 0$ (SD 6.8) $\mu \mathrm{mol} / \mathrm{l}$ ) did not differ significantly from that of the supplemented mothers (1128.3 (sD 407.2) $\mu \mathrm{g} / \mathrm{dl} ; 26.2$ (sD 9.5) $\mu \mathrm{mol} / \mathrm{l})(P>0.05)$ (Fig. 1). All mothers had appropriate serum concentrations of vitamin $\mathrm{E}$.

The CG and SG had similar $\alpha$-tocopherol concentrations in the 0 -h milk $(P>0.05)$. However, the SG had higher $\alpha$-tocopherol concentrations in the $24-\mathrm{h}$ and $7-\mathrm{d}$ milks $(P<0 \cdot 001)$. The $7-\mathrm{d}$ milk of the SG had $35 \%$ more $\alpha$-tocopherol than that of the controls. The $\alpha$-tocopherol concentrations in the 30-d milk of the two groups did not differ significantly $(P>0.05)$.

The $\alpha$-tocopherol concentrations in the 0 -h and 24-h milk samples of the CG did not differ significantly, but the 24-h milk of the SG was $60 \%$ higher in $\alpha$-tocopherol compared with the $0-\mathrm{h}$ milk (Fig. 2). The 24-h milk of the SG met $145 \%$ of the $\alpha$-tocopherol requirement of children aged 0-6 months.
The $\alpha$-tocopherol concentrations of breast milk decreased over time even in the SG. After the significant rise seen in the 24-h milk of the SG, the $\alpha$-tocopherol concentration gradually decreased.

\section{Discussion}

Infant prematurity is associated with many maternal factors such as low pre-gestational weight, age extremes, history of stillbirth or many caesarians, smoking and insufficient weight gain during pregnancy, high blood pressure, genital and urinary tract infections, five or fewer prenatal visits and low educational levels ${ }^{(22,23)}$. The study population presented some risk factors for prematurity.

The serum $\alpha$-tocopherol concentrations of the two groups were appropriate; none of the mothers were vitamin E deficient. Rodríguez et $a l .{ }^{(24)}$, Garcia et $a l .{ }^{(25)}$ and Dimenstein et $a l .{ }^{(26)}$ reported similar results for women who had a term birth. Weber et $a l .{ }^{(27)}$ and Baydas et $a l .{ }^{(28)}$ studied women who had a preterm birth in Germany and Turkey, respectively, and they found higher serum $\alpha$-tocopherol concentrations than those observed in the present study, which may be explained by the different dietary habits in those two countries compared with Brazil.

Table 1. Socio-economic and obstetric characteristics of participating mothers and their newborns

(Mean values and standard deviations; numbers and percentages)

\begin{tabular}{|c|c|c|c|c|c|c|c|}
\hline \multirow[b]{2}{*}{ Variables } & \multicolumn{2}{|c|}{ Control group ( $n 51$ ) } & \multicolumn{2}{|c|}{ Supplemented group ( $n$ 38) } & \multicolumn{2}{|c|}{ Total ( $n$ 89) } & \multirow[b]{2}{*}{$P$} \\
\hline & Mean & SD & Mean & SD & Mean & SD & \\
\hline Maternal age (years) ${ }^{\star}$ & 26 & $5 \cdot 7$ & 26 & $6 \cdot 4$ & 26 & $6 \cdot 1$ & 0.800 \\
\hline \multirow[t]{2}{*}{ Gestational age (weeks)* } & 33 & $2 \cdot 6$ & 34 & $3 \cdot 0$ & 34 & $2 \cdot 8$ & 0.239 \\
\hline & $n$ & $\%$ & $n$ & $\%$ & $n$ & $\%$ & \\
\hline Education level† & & & & & & & 0.110 \\
\hline Incomplete elementary school & 11 & 21 & 08 & 21 & 19 & 21 & \\
\hline Complete elementary school & 04 & 08 & 07 & 18 & 11 & 12 & \\
\hline Incomplete high school & 05 & 10 & 09 & 24 & 14 & 16 & \\
\hline Complete high school & 22 & 43 & 12 & 32 & 34 & 38 & \\
\hline Incomplete higher education & 05 & 10 & 02 & 05 & 07 & 08 & \\
\hline Complete higher education & 04 & 08 & 00 & 00 & 04 & 05 & \\
\hline Marital status* & & & & & & & 0.951 \\
\hline Married & 09 & 18 & 07 & 18 & 16 & 18 & \\
\hline Single & 42 & 82 & 31 & 82 & 73 & 82 & \\
\hline Type of delivery* & & & & & & & 0.776 \\
\hline Vaginal & 21 & 41 & 17 & 45 & 38 & 43 & \\
\hline Caesarian & 30 & 59 & 21 & 55 & 51 & 57 & \\
\hline Parity* & & & & & & & 0.583 \\
\hline Primiparous & 29 & 57 & 19 & 50 & 48 & 54 & \\
\hline Multiparous & 22 & 43 & 19 & 50 & 41 & 46 & \\
\hline Pre-gestational nutritional status $†$ & & & & & & & 0.450 \\
\hline Underweight & 04 & 08 & 03 & 08 & 07 & 08 & \\
\hline Normal weight & 27 & 53 & 14 & 37 & 41 & 46 & \\
\hline Overweight & 12 & 23 & 14 & 37 & 26 & 29 & \\
\hline Obese & 08 & 16 & 07 & 18 & 15 & 17 & \\
\hline Occupation† & & & & & & & 0.083 \\
\hline Employed & 32 & 63 & 20 & 53 & 52 & 58 & \\
\hline Housekeeper & 10 & 20 & 15 & 39 & 25 & 28 & \\
\hline Unemployed & 09 & 17 & 03 & 08 & 12 & 14 & \\
\hline Newborn's birth weight $†$ & & & & & & & 0.202 \\
\hline Very low weight $(<1500 \mathrm{~g})$ & 10 & 20 & 07 & 19 & 17 & 19 & \\
\hline Low weight (1500-2500 g) & 35 & 69 & 21 & 55 & 56 & 63 & \\
\hline Appropriate $(\geq 2500)$ & 06 & 11 & 10 & 26 & 16 & 18 & \\
\hline
\end{tabular}

* Mann-Whitney test.

$\dagger \chi^{2}$ Test. 


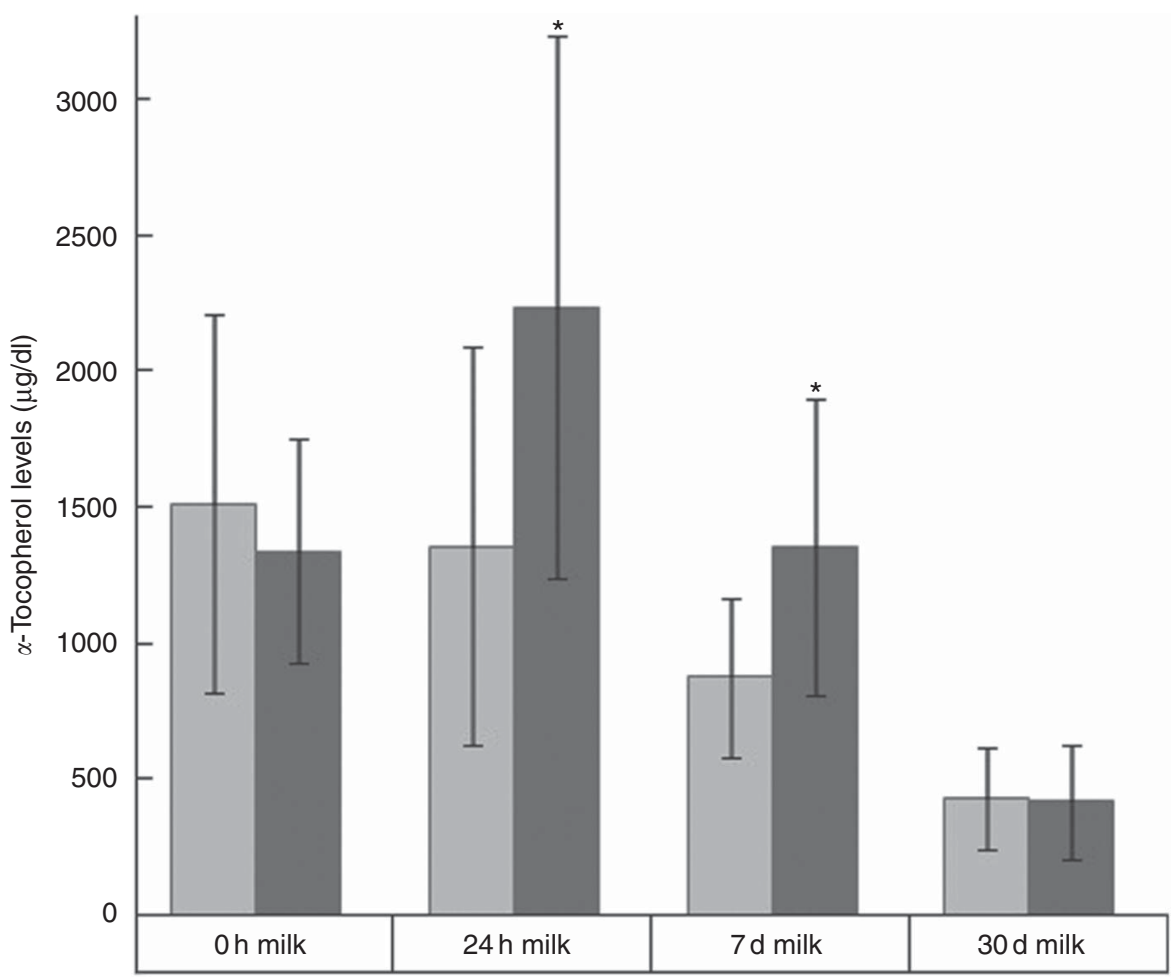

Fig. 1. Mean $\alpha$-tocopherol concentrations $(\mu \mathrm{g} / \mathrm{dl})$ in the 0 -h and 24-h colostrum, 7-d transition milk and 30-d mature milk of the control and supplemented groups. * Significant difference: $P<0.05$. $\square$, Control; $\square$, supplemented. To convert a-tocopherol in $\mu \mathrm{g} / \mathrm{dl}$ to $\mu \mathrm{mol} / \mathrm{l}$, multiply by 0.023256 .

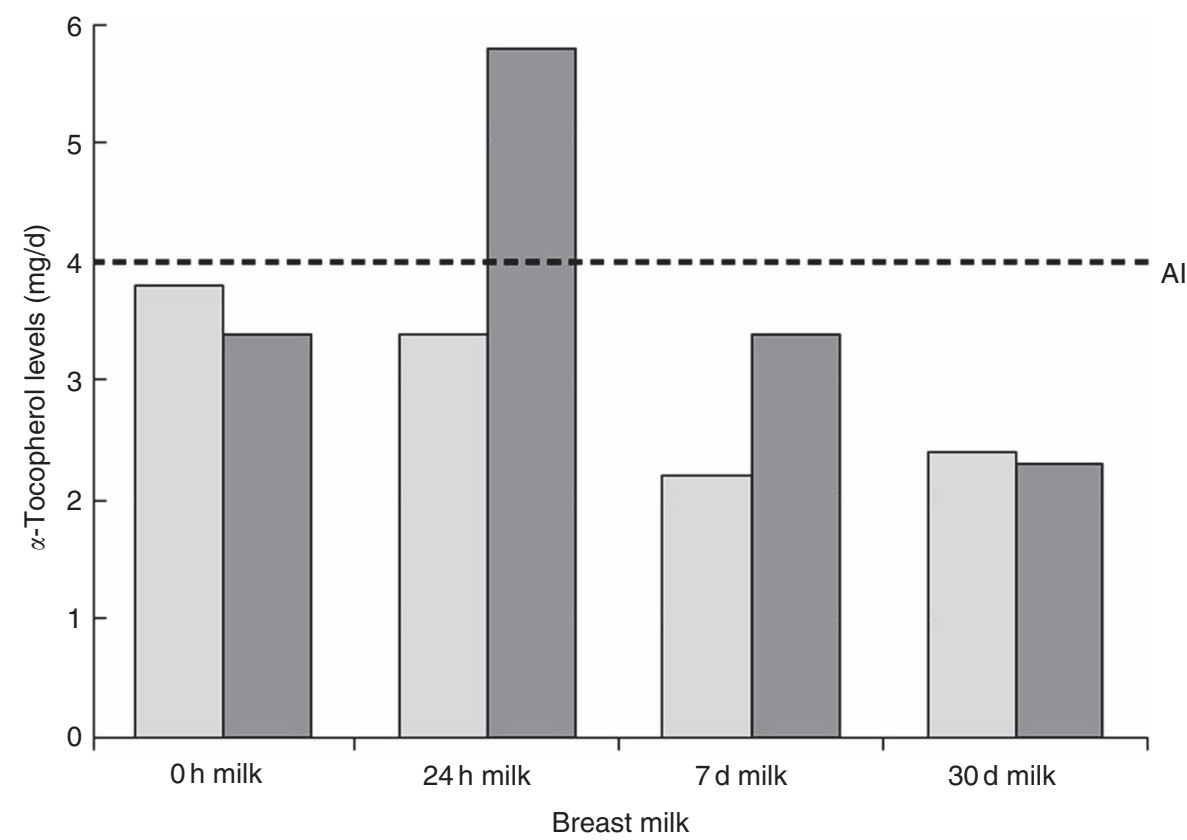

Fig. 2. Infant $a$-tocopherol requirement and amount of $a$-tocopherol provided per day based on the amount of milk consumed on different occasions. $\square$, Control; $\square$, supplemented; Al, adequate intake.

The vitamin E levels in the 0-h colostrum of the CG and SG were similar to those reported by other studies of women who had term births in Brazil ${ }^{(26,29)}$, Turkey ${ }^{(30)}$ and the $\mathrm{USA}^{(31)}$ as well as women who had preterm births in Spain ${ }^{(32)}$ and Brazil ${ }^{(33)}$.

Only the 24-h colostrum of the SG reached the recommended vitamin E level (adequate intake of $4 \mathrm{mg} / \mathrm{d}$ ) for infants aged
0-6 months. However, this recommendation concerns term infants who consume on average $780 \mathrm{ml}$ of milk/ $\mathrm{d}^{(16)}$, which is very different from the amounts consumed by preterm infants. It is possible that the vitamin $\mathrm{E}$ requirement of preterm infants exceeds that of term infants; however, future studies are still needed to determine preterm infant vitamin $\mathrm{E}$ requirements. 
In order to maintain adequate levels of vitamin $\mathrm{E}$ in mature breast milk, mothers should consume dietary vitamin E sources and/or vitamin E supplements ${ }^{(34)}$. This is especially important for those who have had preterm births, as they are a risk group for nutritional deficiencies ${ }^{(4)}$.

In the present study, maternal supplementation with a megadose of natural vitamin E increased the $\alpha$-tocopherol levels of the 24-h and 7-d milks, but did not affect that of the 30-d milk. A limiting factor of the study is that the initial number of participants was reduced. Although there was loss to follow-up for the analysis of $\alpha$-tocopherol in mature milk, the values found were consistent with previous studies that have not administered supplements. Thus, this suggests that the effect of supplementation with one megadose was not sustained until $30 \mathrm{~d}$ after delivery, and it was not influenced by the sample reduction. In addition, longitudinal studies typically have decreased population over time. The positive effect of supplementation on colostrum and transition milk may be related to the elevated synthesis of fatty acids by the mammary gland in the first few days after delivery ${ }^{(35)}$, as vitamin $\mathrm{E}$ is related to lipid metabolism. Jaster \& Wegner ${ }^{(36)}$ observed that lipolysis increases in adipose tissue in the last few weeks of gestation, which may be mediated by higher circulating levels of growth hormone. Growth hormone is lactogenic and essential for human postnatal growth and lipid, protein and mineral metabolism. Regarding lipid metabolism, growth hormone promotes the release of fatty acids and glycerol from adipose tissue and increases the circulation of free fatty acids and their oxidation in the liver ${ }^{(37)}$ Therefore, lactation-related hormones that affect lipid metabolism probably increase the number of mammary gland receptors that capture circulating lipids, including LDL receptors, as LDL is the main vitamin E transporter. Perinatal increase in mammary LDL receptor activity was observed by Debier \& Larondelle ${ }^{(38)}$.

Studies have shown that the transport of vitamin $\mathrm{E}$ to breast milk occurs via distinct and independent mechanisms, in a controlled manner and is limited by receptors, because maternal serum $\alpha$-tocopherol level is not related to colostrum $\alpha$-tocopherol level ${ }^{(26,39)}$. Alternatively, the $\alpha$-tocopherol receptors of the mammary gland may become saturated with high serum tocopherol levels because breast milk tocopherol levels do not increase proportionally.

The mechanisms by which $\alpha$-tocopherol is incorporated into milk have not been entirely clarified, but $\alpha$-tocopherol seems to reach the milk by LDL receptors and some through LDL captured by a process mediated by non-LDL receptors namely, the cell surface receptors SR-B1 - which bind HDL and LDL without lipoprotein internalisation ${ }^{(2)}$. There is also the lipoprotein lipase (LPL) pathway observed in rat experiments ${ }^{(40)}$. LPL activity may be high in the mammary gland and low in adipose tissue, capturing circulating $\alpha$-tocopherol and transferring it to the milk ${ }^{(41)}$.

Another hypothesis is that plasma $\alpha$-tocopherol is transferred to milk according to Michaelis-Menten kinetics for transmembrane active transport ${ }^{(42)}$, using distinct mechanisms that transport vitamin $\mathrm{E}$ to the mammary gland regardless of plasma concentration $^{(43)}$.

Maternal use of vitamin E supplements may also increase the body reserves of this micronutrient. Li et $a l .{ }^{(44)}$ found that $\alpha$-tocopherol supplements have a higher impact on tissue levels of $\alpha$-tocopherol than dietary $\alpha$-tocopherol. Studies on maternal supplementation of vitamin $\mathrm{E}$ after delivery and its effect on breast milk are scarce and inconclusive; some found a correlation between supplementation and breast milk $\alpha$-tocopherol concentration and some did not ${ }^{(14)}$. Clemente et al. ${ }^{(29)}$ assessed maternal supplementation using a natural vitamin E supplement similar to that used in the present study and found similar levels of colostrum vitamin E $24 \mathrm{~h}$ after supplementation.

Our results provide evidence of the importance of maternal supplementation with vitamin E, especially in women with preterm births, in increasing breast milk $\alpha$-tocopherol concentrations. Preterm infants have very low body fat and low reserves of fat-soluble vitamins including vitamin $\mathrm{E}^{(45)}$. Moreover, their red blood cell tocopherol concentrations are low at birth $^{(46)}$, making them functionally vitamin $\mathrm{E}$ deficient ${ }^{(47)}$. As a consensus on parenteral and enteral supplementation does not exist, maternal supplementation is a safe and excellent alternative for meeting the vitamin $\mathrm{E}$ requirements of newborns, supplying enough vitamin $\mathrm{E}$ to protect their bodies against oxidative stress. If supplementation is not done correctly, it may intoxicate the newborn and cause severe health damage ${ }^{(4)}$.

However, a single megadose of $400 \mathrm{IU}$ does not seem to be enough to increase the $\alpha$-tocopherol levels of breast milk for a prolonged period of time. New studies are being developed by this research group to better assess vitamin $\mathrm{E}$ dosages and intervals without placing the mother-child dyad at risk of intoxication.

\section{Acknowledgements}

The authors thank the Januário Cicco Maternity School, the Postgraduate Programme in Biochemistry at Federal University of Rio Grande do Norte and all the mothers who participated in this study.

This research received no specific grant from any funding agency, commercial or not-for-profit sectors. No honorarium, grant or other form of payment was given to anyone to produce the manuscript.

R. D., K. D. d. S. R. and R. A. M. d. N. participated in the conception and design of the study; J. F. P. M., K. D. d. S. R., M. S. R. L., A. C. P. L., R. C. S. D. and A. B. d. S. participated in the acquisition, analysis and interpretation of the data; J. F. P. M. drafted the article. All the authors critically reviewed the manuscript and approved the final version submitted for publication.

There are no conflicts of interest.

\section{References}

1. Bell EF, Hansen NI, Brion LP, et al. (2013) Serum tocopherol levels in very preterm infants after a single dose of vitamin $\mathrm{E}$ at birth. Pediatrics 132, e1626-e1633.

2. Debier C (2007) Vitamin E during pre- and postnatal periods. Vitam Horm 76, 357-373.

3. Dror DK \& Allen LH (2011) Vitamin E deficiency in developing countries. Food Nutr Bull 32, 124-143.

4. Brion LP, Bell EF \& Raghuveer TS (2003) Vitamin E supplementation for prevention of morbidity and mortality in 
preterm infants. The Cochrane Database of Systematic Reviews, Issue 4, CD003665.

5. Edmond K \& Bahl R (2007) Optimal Feeding of the Low Birth Weight Infant. Technical Review. Geneva: WHO.

6. Lawrence RA \& Lawrence RM (2010) Breastfeeding: a guide for the medical professional. St Louis Mosby. Health Sci 7, $171-214$.

7. Isaacs EB, Morley R \& Lucas A (2009) Early diet and general cognitive outcome at adolescence in children born at or below 30 weeks gestation. J Pediatr 155, 229-234.

8. Roberts RJ \& Knight ME (1987) Pharmacology of vitamin E in the newborn. Clin Perinatol 14, 843-855.

9. Thibeault DW (1999) The precarious antioxidant defenses of the preterm infant. J Perinatol 17, 167-181.

10. Delvin EE, Salle BL, Claris O, et al. (2005) Oral vitamin A, E and $\mathrm{D}$ supplementation of pre-term newborns either breast-fed or formula-fed: a 3-month longitudinal study. J Pediatr Gastroenterol Nutr 40, 43-47.

11. Brion LP, Bell EF \& Raghuveer TS (2005) Variability in the dose of intravenous vitamin E given to very low birth weight infants. J Perinatol 25, 139-142.

12. Westergren T \& Kalikstad B (2010) Dosage and formulation issues: oral vitamin E therapy in children. Eur J Clin Pharmacol 66, 109-118.

13. Bell EF, Hansen NI, Brion LP, et al. (2013) Serum tocopherol levels in very preterm infants after a single dose of vitamin $\mathrm{E}$ at birth. Pediatrics 132, e1626-e1633.

14. Lima MS, Dimenstein R \& Ribeiro KD (2014) Vitamin E concentration in human milk and associated factors: a literature review. J Pediatr 90, 440-448.

15. Faul F, Erdfelder E, Lang AG, et al. (2007) G*Power 3: a flexible statistical power analysis program for the social, behavioral, and biomedical sciences. Behav Res Methods 39, 175-191.

16. Institute of Medicine \& US National Academy of Sciences (2000) Dietary Reference Intakes for Vitamin C, Vitamin E, Selenium and Carotenoids. Washington, DC: National Academies Press.

17. World Health Organization (1998) Obesity: Preventing and Managing the Global Epidemic - Report of a WHO Consulation on Obesity. Geneva: WHO.

18. Bauer J \& Gerss J (2011) Longitudinal analysis of macronutrients and minerals in human milk produced by mothers of preterm infants. Clin Nutr 30, 215-220.

19. Souza G, Dolinsky M, Matos A, et al. (2015) Vitamin A concentration in human milk and its relationship with liver reserve formation and compliance with the recommended daily intake of vitamin $\mathrm{A}$ in pre-term and term infants in exclusive breastfeeding. Arch Gynecol Obstet 291, 319-325.

20. Ortega RM, López-Sobaler AM, Martínez RM, et al. (1998) Influence of smoking on vitamin E status during the third trimester of pregnancy and on breast-milk tocopherol concentrations in Spanish women. Am J Clin Nutr 68, 662-667.

21. Nierenberg DW \& Nann SL (1992) A method for determining concentrations of retinol, tocopherol, and five carotenoids in human plasma and tissue samples. Am J Clin Nutr 56, 417-426.

22. Nascimento LFC (2001) Epidemiology of preterm deliveries in Southeast Brazil: a hospital-based study. Rev Bras Saúde Mater Infant 1, 263-268.

23. Barros FC, Victora CG, Barros AJ, et al. (2005) The challenge of reducing neonatal mortality in middle-income countries: findings from three Brazilian birth cohorts in 1982, 1993, and 2004. Lancet 365, 847-854.

24. Rodríguez GP, Alonso DP, Sintes GS, et al. (2002) Vitaminas antioxidantes en un grupo de embarazadas y recién nacidos durante un año de estudio (Antioxidant vitamins in a group of pregnant women and newborns during a year of study). Rev Cuba Aliment Nutr 16, 85-94.

25. Garcia L, Ribeiro K, Araújo K, et al. (2010) Alpha-tocopherol concentration in the colostrum of nursing women supplemented with retinyl palmitate and alpha-tocopherol. $J$ Hum Nutr Diet 23, 529-534.

26. Dimenstein R, Medeiros AC, Cunha LR, et al. (2010) Vitamin E in human serum and colostrum under fasting and postprandial conditions. J Pediatr 86, 345-348.

27. Weber D, Stuetz W, Bernhard W, et al. (2014) Oxidative stress markers and micronutrients in maternal and cord blood in relation to neonatal outcome. Eur J Clin Nutr 68 , 215-222.

28. Baydas G, Karatas F, Gursu MF, et al. (2002) Antioxidant vitamin levels in term and preterm infants and their relation to maternal vitamin status. Arch Med Res 33, 276-280.

29. Clemente HA, Ramalho HMM, Lima MSR, et al. (2014) Maternal supplementation with natural or synthetic vitamin $\mathrm{E}$ and its levels in human colostrum. $J$ Pediatr Gastroenterol Nutr 60, 533-537.

30. Orhon FS, Ulukol B, Kahya D, et al. (2009) The influence of maternal smoking on maternal and newborn oxidant and antioxidant status. Eur J Pediatr 168, 975-981.

31. Gossage CP, Deyhim M, Yamini S, et al. (2002) Carotenoid composition of human milk during the first month postpartum and the response to $\beta$-carotene supplementation. Am J Clin Nutr 76, 193-197.

32. Quiles JL, Ochoa JJ, Ramirez-Tortosa MC, et al. (2006) Coenzyme Q concentration and total antioxidant capacity of human milk at different stages of lactation in mothers of preterm and full-term infants. Free Radic Res 40, 199-206.

33. Grilo EC, Lira LQ, Dimenstein R, et al. (2013) Influence of prematurity and birth weight on the concentration of alphatocopherol in colostrum milk. Rev Paul Pediatr 31, 473-479.

34. Tokuşoğlu O, Tansuğ N, Akşit S, et al. (2008) Retinol and $\alpha$-tocopherol concentrations in breast milk of Turkish lactating mothers under different socio-economic status. Int J Food Sci Nutr 59, 166-174.

35. Boersma ER, Offringa PJ, Muskiet FA, et al. (1991) Vitamin E, lipid fractions, and fatty acid composition of colostrum, transitional milk, and mature milk: an international comparative study. Am J Clin Nutr 53, 1197-1204.

36. Jaster EH \& Wegner TN (1981) Beta-adrenergic receptor involvement in lipolysis of dairy cattle subcutaneous adipose tissue during dry and lactating state. I Dairy Sci 64, $1655-1663$

37. Hurley KM, Black MM, Papas MA, et al. (2008) Variation in breastfeeding behaviours, perceptions, and experiences by race/ethnicity among a low-income statewide sample of Special Supplemental Nutrition Program for Women, Infants, and Children (WIC) participants in the United States. Matern Child Nutr 4, 95-105.

38. Debier C \& Larondelle Y (2005) Vitamins A and E: metabolism, roles and transfer to offspring. Brit J Nutr 93, 153-174.

39. de Lira LQ, Lima MSR, de Medeiros JMS, et al. (2013) Correlation of vitamin A nutritional status on alpha-tocopherol in the colostrum of lactating women. Matern Child Nutr 9, $31-40$.

40. Martínez S, Barbas C \& Herrera E (2002) Uptake of alphatocopherol by the mammary gland but not by white adipose tissue is dependent on lipoprotein lipase activity around parturition and during lactation in the rat. Metabolism 51, 1444-1451.

41. Amazan D, Cordero G, López-Bote CJ, et al. (2014) Effects of oral micellized natural vitamin E (d- $\alpha$-tocopherol) v. synthetic 
vitamin $\mathrm{E}$ ( $\mathrm{dl}$ - $\alpha$-tocopherol) in feed on $\alpha$-tocopherol levels, stereoisomer distribution, oxidative stress and the immune response in piglets. Animal 8, 410-419.

42. Mardones P \& Rigotti A (2004) Cellular mechanisms of vitamin E uptake: relevance in $\alpha$-tocopherol metabolism and potential implications for disease. J Nutr Biochem 15, 252-260

43. de Azeredo VB \& Trugo NM (2008) Retinol, carotenoids, and tocopherols in the milk of lactating adolescents and relationships with plasma concentrations. Nutrition 24, 133-139.

44. Li Y, Sen A, Ren J, et al. (2015) Effects of vitamin E from supplements and diet on colonic $\alpha$-and $\gamma$-tocopherol concentrations in persons at increased colon cancer risk. Nutr Cancer 67, 73-81.

45. Dju MY, Mason KE \& Filer LJ Jr (1952) Vitamin E (tocopherol) in human fetuses and placentae. Etudes Neonatales 1, 49-62.

46. Kelly FJ, Rodgers W, Handel J, et al. (1990) Time course of vitamin $\mathrm{E}$ repletion in the premature infant. $\mathrm{Br} J \mathrm{Nutr}$ 63, 631-638.

47. Cornblath M, Gordon HH \& Nitowsky HM (1956) Studies of tocopherol deficiency in infants and children. II. Plasma tocopherol and erythrocyte hemolysis in hydrogen peroxide. AMA J Dis Child 92, 164-174. 